\title{
OF STIMULI AND METAPHORS: THERAPEUTIC STORYTELLING (FAIRY TALE THERAPY) IN THE SNOEZELEN ROOM
}

\author{
Agnieszka Smrokowska-Reichmann
}

\begin{abstract}
There are clear commonalities between the Snoezelen method and therapeutic storytelling (fairy tale therapy). When conducting fairy tale therapy in a Snoezelen room, we deal with the synergetic effect of sensory stimuli (characteristic of Snoezelen) and imaginary stimuli (characteristic of fairy tale therapy). Both the symbolic space of a fairy tale and the sensory space of Snoezelen constitute a "different" world. Each type of art therapy, including bibliotherapy and the fairy tale therapy it contains, affect the senses, thus supporting sensory memory. The article analyses the theoretical and practical aspects of conducting fairy tale therapy in a Snoezelen room with children and with adults.
\end{abstract}

\section{Keywords}

Snoezelen, therapeutic storytelling, fairy tale therapy, sensory stimuli, bibliotherapy.

\section{Comparison between Snoezelen therapy and fairy tale therapy}

There are clear commonalities between Snoezelen therapy and the therapeutic use of fairy tales. When conducting fairy tale therapy in the Snoezelen Room, we are dealing with the synergistic effect of sensory stimuli (characteristic of Snoezelen therapy) and imaginative stimuli (characteristic of fairy tale therapy). (Bera, 2017). This is not surprising, since each type of art therapy (including bibliotherapy and fairy-tale therapy) affects the senses, thereby supporting sensory memory (Modrak 2016).

The comparative analysis of Snoezelen sessions and fairy tale therapy for children (proposed by Alicja Bera) can be reduced to the following points:

1. Both the symbolic space of fairy tales and the sensory space of Snoezelen constitute a "different" world, which children relate to in a special way, precisely because it differs significantly from the everyday reality surrounding them. 
2. In the Snoezelen Room, there is a wealth of sensory stimuli; while fairy tale therapy presents a wide range of imaginative stimuli.

3. In fairy tale therapy, an individual approach to the participant is extremely important, e.g., the choice of a favourite text of the child (to produce greater therapeutic effects). In the Snoezelen Room there is also a maximally individualized approach towards the participant, manifested by, for example, the appropriate selection of stimuli, guaranteed by the methodological principles of Snoezelen.

4. During both fairy tale therapy and Snoezelen therapy, it is essential to maintain control over the session. In the case of fairy tale therapy, the therapist must vet the content according to the age, level of development, and health of the participants. In the Snoezelen Room, the therapist must select the stimuli according to the health condition of a particular participant and their level of fitness and development, and must also take possible contraindications into account.

5. Both the person conducting the fairy tale therapy and the person conducting the Snoezelen session must be creative and responsive. Fairy tale therapy sessions and sessions in the Snoezelen Room make high demands of the therapist, since neither can be run according to a precise plan.

6. Another common feature of fairy tale therapy and sessions in the Snoezelen Room is their positive appeal to the recipient.

(Bera, 2017; see also: Rawa-Kochanowska, Zawadzka 2015, Głodkowska 2001, Konieczna 2005, Molicka 2011, Szaga 2014).

The general observations above encourage reflection on some of the more detailed aspects of fairy tale therapy in relation to Snoezelen therapy.

\section{Imagination - creativity - development}

Originally, fairy tales were not only intended for children. From the dawn of human history, such narratives have expressed the human longing for happiness, the approval of good, the condemnation of evil, and the affirmation of justice. They prove the power of human imagination and creativity, and, at the same time, stimulate emotional and intellectual development. For these reasons, fairy tales are highly valued and constantly revisited in psychology and pedagogy. In the world of fairy tales, on one hand, the impossible becomes possible and there are no problems without a solution, but on the other hand, the heroes encounter various difficulties and dangers, which they must strive to overcome. Properly selected and presented during fairy tale sessions, narratives can be soothing and therapeutic, since they show how to surmount obstacles, how to actively confront unfavourable circumstances, and how to find confidence in oneself and one's competences. It is also worth noting that if the fairy tale therapy session is conducted correctly, the therapeutic potential of fairy tales is activated naturally, as if "by accident". Imagination, creativity, development, overcoming obstacles, soothing, developing competences - such terms can also be applied to Snoezelen therapy. Similarly to fairy 
tale therapy, in the Snoezelen Room the therapeutic effects happen "by themselves", as if "by accident" - provided the person conducting the session scrupulously follows all eight methodological principles of Snoezelen. In general, both fairy tale therapy and Snoezelen sessions are about activating positive emotional, cognitive, and social processes. The narrative, although it does not require an immediate and precise response, is nevertheless an unambiguous stimulus, capable of generating a wide spectrum of reactions, and is, thus, an effective way to galvanize the listener. The same can be said for sessions in the Snoezelen Room, except that in this case the activating factor is not the words (or not only the words), but (also) various types of sensory stimuli.

\section{The role of the therapist}

Preparation for both fairy tale therapy and Snoezelen sessions first requires sensitization of the therapist. In Snoezelen therapy it can be done, for instance, by visualization, as proposed by Hulsegge and Verheul, and by the therapists experiencing the Snoezelen space for themselves before taking their first patients into the Snoezelen Room. The sensitization of Snoezelen therapists has been codified as part of the code of correct fundamental attitudes and supervision (Hulsegge, Verheul, 1986). In the case of those conducting fairy-tale therapy, sensitization training is taken, which may, for example, take the form of an exercise known as "experiencing" fairy tales (see Kallen, 1999). The stages of such training might be as follows:

1. After reading the fairy tale, the therapist decides which character he/she most identifies with (whether a major or a minor character).

2. The therapist uses his/her own words to tell the fairy tale, and attempts to create a vivid and realistic narrative. The present tense is used.

3. The therapist makes a list of characters, creatures, and things that play a role in the fairy tale.

4. The therapist in turn tries to empathize with each of the characters listed on the list (auxiliary questions: What does the character feel? What do they want? What are their plans?).

5. The therapist outlines conflicts and tensions between the characters (auxiliary questions: Who seems to be the most powerful being? Who dominates? Who is [apparently] the least important?).

6. The therapist tries to come up with solutions other than that proposed in the fairy tale.

7. The therapist tries to answer the following questions: Does this fairy tale reflect any part of my life? Does it say anything about my situation, my problems? Does it outline a course of action with which I agree?

As we can see, although the leading of Snoezelen therapy sessions and fairy tale therapy sessions may seem simple, straightforward, and even fun in the eyes of non-professionals - in reality, it places high demands on the therapist and must be meticulously prepared for. 


\section{The role of the text and space}

Both fairy tale sessions and Snoezelen sessions involve not so much a dialogue as a trialogue. In the case of fairy tale therapy, the parties are: the participants the therapist - the text (since the text also "works" on the listener and "demands" a response - it is "alive"). In the case of Snoezelen therapy, the parties are: the participant - the therapist - the Snoezelen space (i.e., the equipment, their arrangement, and the stimulation produced by them). A well-arranged and well-equipped Snoezelen Room also "works" on the participant, "demands" a reaction from him/her, and resembles a "living organism".

Like fairy tales, the concept of Snoezelen is the product of human imagination and creativity. At the same time (again, like fairy tale therapy) Snoezelen therapy awakens the imagination and creativity of the participants of the session. In younger participants of fairy tale therapy, stories often evoke surprise, enchantment, and delight - the very reactions that occur in those who enter the Snoezelen Room for the first time. The only difference is that enchantment with the Snoezelen Room may occur not only in children, but also in adults. One of my students exclaimed: "It's like Narnia in here!" when he entered Snoezelen Room for the first time; this spontaneous statement from a young adult perfectly illustrates how close the "other world" of Snoezelen is to the world of fairy tales.

The role of the text in fairy-tale therapy, and the space in Snoezelen therapy are also important since both text and space constitute a medium that facilitates communication with a person with whom communication is difficult - mainly small children, but also people with limited intellectual abilities. Both the text of the fairy tale and the multisensory space of the Snoezelen Room become a kind of transmission belt, used to convey a message that, in a different form, the addressee would not be able to assimilate or would not fully understand. However, there is another very significant common feature between the fairy tale text and the Snoezelen space. The basic requirement for a therapeutic text is that it should arouse the child's curiosity (as well as being entertaining and enjoyable for them). The fairy tale must, therefore, be well told - the narrative should be lively, fast paced, and should appeal to the child's imagination. It is important that the child does not become bored during fairy tale therapy, and the same applies to Snoezelen therapy. The space of the Snoezelen Room, the type of stimuli, and the way they are provided should also be attractive, entertaining, and enjoyable for the child. Therefore, it is important to not only conduct free Snoezelen sessions, but also to skilfully prepare and conduct thematic sessions and sessions based on a scenario. The Snoezelen Room should surprise the child again and again, just as new fairy tales continue to surprise them during fairy tale therapy sessions. By conducting fairy-tale therapy in the Snoezelen Room, the therapist's task is somewhat easier, since the multisensory space of the Snoezelen Room makes the narrative more attractive, and the narrative, in turn, can serve as the guiding motif for the scenario.

Opinion is divided on whether the texts during fairy tale therapy should be simply read by the therapist or told. Generally speaking, a story is better when told than read; 
nevertheless, a well-read story is better than a badly-told one. The text of the fairy tale may need to be repeated in subsequent sessions, for various reasons. It is important to remember that what matters most is the fidelity and accuracy of the repeated text, especially with children and seniors with cognitive problems, since listening to what is already known creates a sense of security in these participants. Therefore, if the therapist is not sure whether he/she will be able to tell a story in the same (or very similar) way for a second or third time, it is better for him/her to read it. Here the question arises of which voice to tell (or read) the story in. The voice of the therapist during both fairy tale therapy and Snoezelen therapy is essential (although this is a topic for further analysis). As far as fairy tale therapy itself is concerned, the therapist's voice should convince the participant that the fairy tale impresses the therapist himself/herself, that he/she is in some way moved by it. In relation to Snoezelen therapy, the principle of the correct attitude implies the therapist's need for full involvement in the world of Snoezelen. Excessive changes in voice are strongly discouraged. It is very easy to overdo the effect, with unintentionally comic results. The story should not be told (read) in an overly suggestive manner; as in Snoezelen therapy, the voice of the fairy-tale therapist must be more or less neutral to better reflect the statements of the characters appearing in the fairy tale, and to allow participants the space to interpret and react to the narrative freely. In both fairy tale therapy and Snoezelen therapy, the therapist must avoid imposing his/her opinion or attitude on the participant - it is the text and the multisensory space that should "work" on the participant.

The metaphorics and symbolism of fairy tales, and the therapist's withdrawal from a dominant role may make it difficult to characterise fairy tale therapy as an intervention, which can also be the case with Snoezelen therapy. Of course, some clearly formulated rules apply to both fairy-tale therapy and Snoezelen. In both cases, the therapist maintains the role of organizer of activities, in the sense that he/she presents various options to patients and provides certain directions. However, in both fairy tale therapy and Snoezelen the participant's autonomy should not be restricted.

\section{Integrating fairy tale therapy in Snoezelen classes with children and seniors}

Most of the fairy tales used in fairy tale therapy can be divided into three acts. This simple scheme makes it easy to integrate fairy tale therapy into scenarios in the Snoezelen Room: - Act one, the introduction, takes place in a fairy-tale world, but it is also possible to meet its elements in reality; for example, a family consisting of a mother, father, and children is common to fairy tales and everyday life.

- Act two clearly plays out in an area of symbolism and magic; for example, one of the children is turned into an animal by a magic spell, and special actions are required to break the spell and to return the child to his/her true form.

- Act three is the ending, in which a happy solution is found, and the situation of the heroes is as good if not better than at the beginning. 
The Snoezelen Room provides the right conditions and opportunities to illustrate these stages, using Snoezelen equipment and devices, as well as additional items brought to the Snoezelen Room specially for a particular scenario. Illustrations play an important role in fairy tale books for children. The Snoezelen Room can act as a giant illustration into which the children physically enter and experience the fairy tale. The length of the average session of fairy tale therapy and Snoezelen therapy for children is also similar, at about 30 minutes.

Psychologists and psychotherapists emphasize that the strength of fairy tales lies in their deep understanding of the various stages of life and the problems that are typical of these stages. Attention should be given to the special messages of fairy tales concerning not only the world of children, but also the world of adults. For example, long before ideas of emancipation and equal rights, fairy tales told stories of women taking on the fate of their family and even their country. A woman in a fairy-tale world is not the "weaker sex" at all, and her biological features do not negatively determine her. On the contrary, the heroines of fairy tales can make superhuman efforts and achieve goals that are beyond others. It can even be said that in fairy tales the roles and possibilities of a woman are presented even more comprehensively than the roles and possibilities of a man. Girlfriend, beloved, wife, mother, stepmother, sister, daughter, queen, fairy, witch, mother-in-law, mermaid, etc. - these good (and sometimes bad) women shape the fate of others, and they decisively follow their own path in life.

These and similar aspects of fairy tales explain why suitably adapted fairy tale therapy can also be used when working with adults (e.g., in psychotherapy). Snoezelen therapy is also open to adults, including the elderly.

Indeed, seniors respond extremely well both to fairy tale therapy sessions and Snoezelen therapy sessions. They may be cognitively able seniors, but also seniors with pre-dementia or dementia. Of course, sessions in the Snoezelen Room with seniors (cognitively able, or suffering from forms of dementia) are a subject deserving separate consideration. However, with regard to fairy tale therapy with seniors, we should note that they willingly listen to "classics", that is, well-known fairy tales that they knew during their childhood, and perhaps told their own children and grandchildren. It is best to choose stories that are just over ten minutes long, so that even seniors with cognitive limitations will most likely maintain concentration throughout the entire duration of the piece and can grasp the entire message. If the fairy tale is longer, it is advisable to introduce breaks (e.g., for music, singing together, other sensory stimuli, such as taste stimuli, or conversations about a fragment of the story already heard), particularly for seniors with dementia.

Seniors have a long experience of life, and since they have already fulfilled most of the basic goals in life, there is no need to attempt to specially form or correct anything in these people. Therefore, in fairy tale therapy with this group of recipients, we can set slightly less "serious" goals. It is worth trying to find texts that create a good mood and make the participants smile or even laugh. After all, old age is often a period in which we experience loss, the repertoire of our behaviours narrows, and our health worsens; therefore, good humour produced in the Snoezelen Room is therapeutic in the full sense of the word. On the other hand, many seniors also expect deeper texts that can reference their wisdom from life, their own opinions, and other autobiographical aspects. 
In the Snoezelen Room, there are optimal conditions for conducting both the first and the second variant of fairy tale therapy with the elderly.

For the purposes of fairy tale therapy conducted in the Snoezelen Room, the therapist can compose his/her own texts, but he/she can also use classic fairy tales. Depending on the group of participants i.e., children or seniors, different layers of meaning can be revealed. Below, is an example of such use of a fairy tale: "Candles" by Hans Christian Andersen.

\section{Possible additional accessories:}

- candles (for safety reasons in lantern form, i.e., closed inside a housing; lanterns marked to differentiate "better" and "worse" candles)

- a wicker basket

- apples

- potatoes baked in their jackets

- bows and ribbons

- „sewing" materials (for safety reasons, no needles and threads - only make-believe materials)

- shiny aluminium foil, spotlights, LED lamps (to create the glow that permeates this fairy tale)

\section{Possible use of Snoezelen equipment:}

- hanging optic fibres to represent the ballroom walls (colour setting: white and yellow)

- light-and-sound track as the floor of the ballroom

- optic fibres spread on the floor, covered with transparent tulle in white and gold (ballroom floor)

- bubble tubes in yellow (to represent the glow of the candles in the ballroom)

- CD recordings: e.g., a waltz

- low pouffes/seats in a darker corner of the Snoezelen Room (to represent the poor widow's flat)

\section{With children, the focus of the session will be:}

- the depiction of a candle as the "narrator" (a fairy-tale candle that speaks; perhaps it is magic?)

- role playing, dancing, cooperation in a group

- emphasizing messages such as: children finding equal joy in very different things, love between siblings, love between a mother and her children

\section{With seniors, the focus of the session will be:}

- interpretation of the symbolic layer of the fairy tale

- speaking about concepts such as justice, love, fulfilment, self-realization, sacrifice, happiness

- elements of autobiographical work, e.g., difficult, but also beautiful memories from one's own childhood, differences in living standards 


\section{Possibilities of multisensory stimulation in both cases:}

- visual stimuli

- auditory stimuli

- tactile stimuli

- taste and olfactory stimuli.

\section{References}

Bera A. (2017). Baśniowa przestrzeń Sali Doświadczania Świata jako miejsce recepcji uniwersalnych wartości międzyludzkich, Ogólnopolska Konferencja Naukowa „Terapeutyczny i pedagogiczny potencjał oddziaływania polisensorycznego. Wokół teorii i praktyki Snoezelen (Sali Doświadczania Świata), Wrocław 20-21.05.2017 (notatki z wykładu). [The fairy-tale space of the World Experience Room as a place for the reception of universal interpersonal values, Polish National Scientific Conference "Therapeutic and pedagogical potential of polysensory influence. Around the theory and practice of Snoezelen (the World Experience Room)", lecture notes]

Głodkowska J. (2001). Zabawa i nauka w kręgu baśni. Metoda wspomagania wrażliwości edukacyjnej dziecka lekko upośledzonego umysłowo w wieku wczesnoszkolnym, [Fun and learning in the circle of fairy tales. A method of supporting the educational sensitivity of a mildly mentally retarded child in early school age]. Warszawa: Akademia Pedagogiki Specjalnej im. Marii Grzegorzewskiej.

Hulsegge, J. \& Verheul, A. (1986). Snoezelen, een andere wereld, [Snoezelen, another world]. Uitgeverij Intro, Nijkerk.

Kallen, D. (1999). Märchen in der psychotherapeutischen Behandlung von Kinder, [Fairy tales in psychotherapy with children]. München: Grin Verlag.

Konieczna, E. (2005). Baśń w literaturze i w filmie: rola baśni filmowej w edukacji filmowej dziecka w wieku przedszkolnym, [The fairy tale in literature and in movies: the role of the movie fairy tale in the movie education of a preschool child]. Kraków: Universitas.

Modrak, M. (2016). Pamięć sensoryczna, czyli myśleć ciałem. Doskonalenie zasobów pamięci zmysłowej, [Sensory memory, i.e. body thinking. Improving sensory memory resources]. Warszawa: Diffin.

Molicka, M. (2011). Biblioterapia i bajkoterapia. Rola literatury w procesie zmiany rozumienia świata społecznego i siebie, [Bibliotherapy and fairy tale therapy. The role of literature in the process of changing the understanding of the social world and oneself]. Poznań: Media Rodzina. 
Szaga, H. (2014). Bajki terapeutyczne, [Therapeutic fairy tales]. Kraków: Impuls.

Zawadza, E. \& Rawa-Kochanowska A. (2015). Magiczny świat baśni i bajek: metafory i symbole w procesie wspomagania dziecka w rozwoju, [The magical world of fairy tales: metaphors and symbols in the process of supporting a child's development]. Warszawa: Diffin.

\section{Author}

Smrokowska-Reichmann, Agnieszka, Ph.D.

Zakład Terapii Zajęciowej, Instytut Nauk Stosowanych

Akademia Wychowania Fizycznego w Krakowie

31-571 Kraków Al. Jana Pawła II 78

agnieszka.reichmann@gmail.com 